\title{
TINE TJØRNHØJ-THOMSEN
}

\section{SLAEGTSKAB MED DYR}

For Ida var det tidligere af helt afgørende betydning, at hun skulle have både uddannelse og arbejde, før hun fik børn, fortæller hun antropologen en dag. Men da det blev klart for hende, at hun havde fertilitetsproblemer, var hun så småt begyndt at revidere arbejdets betydning. Det forekom hende at være en vanvittig tanke at skulle gennem et belastende behandlingsforløb for (måske) at få børn og så aflevere dem kl. 7 om morgenen i en børneinstitution og hente dem igen kl. 17. Hvis hun fik børn, kunne hun godt forestille sig helt at opgive sit arbejde. I hvert fald i de første tre år. „Nu må du ikke grine af mig“, siger hun og fortæller, at sådan har hun fået det, efter at hun har fået hund. Før skulle hun lige det ene og det andet og syntes, at det var vigtigt at få købt alle tilbudsvarerne. Men nu er det blevet magtpåliggende at komme hjem til hunden. Den skal luftes og skal ikke være alene for længe: „Jeg har fornemmet, at det at elske noget eller have noget at drage omsorg for, det gør altså, at andre ting virkelig kan komme i anden række.“

Det er fortællinger som ovenstående, der danner baggrunden for denne artikel om slægtskab med dyr. I forbindelse med en undersøgelse af barnløshed og forplantningsteknologi i Danmark blev jeg ofte konfronteret med dyr (Tjørnhøj-Thomsen 1999). ${ }^{1}$ Dyrene optrådte på forskellig vis i de barnløses fortællinger om deres barnløshed, ligesom jeg også mødte dyr i mange af de barnløses hjem. Tanker om dyrs og menneskers fælles natur og reproduktive liv og viden om og konkrete erfaringer med dyr blev mobiliseret som måder at fortælle om og overveje børneønsket og barnløsheden på.

Men hvordan og hvorfor optræder dyr i fortællinger om barnløshed? Og hvad fortæller det mere generelt om menneskers forhold til dyr og til hinanden? Hvad er det for eksempel, der gør, at relationen til en hund kan ændre synet på børn og arbejdsliv? I det følgende lader jeg de måder, hvorpå barnløse „,ænker med dyr“ (jf. Lévi-Strauss 1991) danne baggrund for en mere generel diskussion af de forskelligartede former for forbindelser og forbundethed mellem mennesker og dyr, som jeg - måske provokerende, men som det forhåbentlig vil fremgå analytisk relevant - definerer som slægtskab. Slægtskab fungerer dermed som en analytisk ramme for diskussionen og inddrager indsigter og begreber fra en række, især nyere, slægtskabsstudier til at belyse menneskers slægtskab med dyr (Carsten 2000; Schneider 1980; Howell 2001).

Før jeg går i gang, er det væsentligt at understrege to forhold. For det første er barnløshed også i mere generelle og vante termer et oplagt felt for et antropologisk studie af slægtskab. Såvel selve barnløsheden som overvejelser og beslutninger om den 
medicinske teknologi, der skal afhjælpe den, bringer de ufrivilligt barnløse i en uventet og uvant situation og ind i et ,refleksivt rum“ (Turner 1967), hvor meget af det, de tager for givet om tilblivelse, forældreskab, familie, køn og identitet og slægtskab, må tages op til revision og omdefineres (Tjørnhøj-Thomsen 1999). At åbne et etnografisk vindue til dette rum giver indblik i nogle af de forestillinger og praksisser, der kendetegner moderne, dansk slægtskab. Her hører dyrene også med, som det vil fremgå. For det andet, at kæledyrenes tilstedeværelse i de barnløses liv ikke kan siges at være hverken særegen eller overraskende. Der er altså ikke belæg for at konkludere, at barnløse, fordi de ikke kan få børn, skulle være særlig disponerede eller motiverede for at knytte sig til kæledyr, selv om det er én blandt mange indfødte forestillinger om barnløshedens psykologiske og sociale implikationer. De barnløses fortællinger er, som det vil fremgå, blot én version af det velkendte og interessante fænomen, at dyr - og i særdeleshed kæledyr - har tilegnet sig en central placering som både objekter og aktører i moderne, vestlige menneskers tankeverdener, sociale liv, fællesskaber og selvforståelser.

Selv om det er dyrs forskelligartede tilstedeværelse i det barnløse felt, der er det primære afsæt for denne artikel, inddrager jeg også andre antropologiske undersøgelser af dyrefeltet samt egne observationer fra andre empiriske kontekster. Det har været interessant at erfare, at når den etnografiske opmærksomhed rettes mod dyr-menneskerelationer, byder det etnografiske materiale sig til på en nærmest overvældende måde, og det afslører de komplekse og til tider paradoksale forbindelser mellem mennesker og dyr (jf. Franklin 2001). Det er sådanne forbindelser, jeg interesserer mig for her. Mere specifikt fokuserer jeg på de forbindelser og betydninger, der skabes, når mennesker interagerer med og drager analogier mellem mennesker og dyr. Analogidragning er en sammenligningsproces, der består i at etablere en forbindelse mellem to fænomener eller betydningsdomæner ved at artikulere, hvad de har til fælles, og altså hvordan de ligner hinanden. Men analogidragning fungerer ikke, hvis der ikke antages at være en forskel mellem fænomenerne, idet det ikke er muligt at drage analogier mellem fænomener, der er ens (Strathern 1992a:72-3). ${ }^{2}$ Det vil sige, at når mennesker drager analogier mellem mennesker og dyr, beskæftiger de sig med både ligheder og forskelle. Det betyder ikke, at der hersker enighed om forskellighedens grænseskel eller lighedens beskaffenhed, eller at disse forhold er stabile. Tværtimod. Analytisk set indebærer det en interesse for, hvordan ligheder og forskelle bliver til og mobiliseres i forskellige sociale sammenhænge, og dermed også opmærksomhed på kulturelle klassifikationsprocesser, grænsesætninger, in- og eksklusionsprocesser og social differentiering.

Den britiske antropolog Marilyn Strathern skriver, at kultur konstitueres og kommer til udtryk i de måder, hvorpå analogier forbinder og adskiller forskellige betydningsdomæner (Strathern 1992b:33). Kultur beror dermed på, påpeger Strathern, hvilke analogier der i en given kontekst er mulige eller umulige at drage og derved også på analogidragningens elasticitet og potentielle brudpunkt. En velkendt analogi i en vesteuropæisk kontekst er den mellem børn og kæledyr. Der er masser af eksempler på, at mennesker i nogle sammenhænge ikke tøver med at omtale og behandle deres kæledyr som børn (Greenebaum 2004) eller taler om deres hund som en nær ven (Sanders 1999). Men der er også, som det vil fremgå, tilsvarende masser af eksempler på, at analogidragningen mellem dyr og mennesker har en ydergrænse. Så samtidig med at et begreb som „hundebedste" (se senere) fungerer i en dansk kontekst, vil det at tænke på og tale om sin hund som sin kæreste eller far vække forundring og panderynken. I de følgende afsnit skal vi 
se nøjere på disse forskelligartede aspekter af menneskers slægtskab med dyr - og dette slægtskabs begrænsning.

\section{Menneskedyr}

Det hørte ligesom med. Nu var vi ikke to kærester mere, nu var vi et par. Og der hører altså børn med. Det gør der. Jeg ved ikke hvorfor, men det gør der [tænkepause og let irriteret]: Ja, jeg ved godt, du vil have ord på det [tænkepause igen]. Altså, vi har talt om det på den måde, at når vi nu basalt er dyr, og den basale drivkraft i alle dyr, det er nu engang at få afkom, og det ligger altså også i os. Og jeg tror, det helt basalt er menneskedyret, som siger, I skal have børn, vi skal have afkom.

I dette udsagn giver en mand sit bud på, hvorfor det er vigtig at få børn. Han har svært ved at finde de rigtige ord, og hans åbenlyse irritation over at skulle begrunde og verbalisere dette ønske (her over for antropologen) er typisk. Langt de fleste ufrivilligt barnløse er voldsomt irriterede over, at de - i modsætning til mennesker, der får børn på almindelig vis, og når de ønsker det - i særlig grad skal begrunde og legitimere ønsket om børn. Det forhold, at de barnløse må ty til medicinsk-teknologiske løsninger og måske også give afkald på biologisk slægtskab, bringer dem i en situation, hvor de må naturalisere børneønsket for derved at betone såvel børneønsket som fertilitetsbehandlingens legitimitet. ${ }^{3}$ Udsagn som, at det er ,,menneskedyret, der siger, at vi skal have afkom“, eller at „det er fundamentalt at danne en familie, der hører børn til, det er indbygget i de fleste af os som art", er gode eksempler på, hvordan ligheder mellem mennesker og dyr mobiliseres som en naturalisering og følgelig legitimering af børneønsket. Naturaliseringen af børneønsket sker ved at drage analogier til dyreverdenen, og derved betones menneskers formodede artsfællesskab med dyr og de reproduktive drifter, instinkter og funktioner, mennesker antages at have til fælles med dyr. „Vi ved, hvad der er naturligt, ved at sammenligne os med dyr“, skriver den amerikanske antropolog Anna Lowenhaupt Tsing og påpeger, at naturalisering netop består i at tildele naturen en egen uafhængig handlekraft (Tsing 1995:136-7). Naturen og dyrene har imidlertid en flertydig status i vesteuropæisk kosmologi og tankegang (Yanagisako \& Delaney 1995). Naturen er både guddommelig, hellig og egenrådig, men den er også genstand for inspektion, intervention og kontrol (Tjørnhøj-Thomsen 1999:267). Det både attraktive og farlige ved naturen og dyrene er, at de igen og igen undslipper menneskets kontrol og handler på egen hånd. ${ }^{4}$ Det interessante er, at naturens egenrådighed (her: menneskedyret) i nogle tilfælde mobiliseres som legitimering og moralsk berettigelse af særlige ønsker, behov og handlinger (som ønsket om børn), mens det $\mathrm{i}$ andre tilfælde er socialt, moralsk og etisk problematisk, hvis mennesker tillader naturen både i og uden for mennesket at handle egenrådigt og ukontrolleret (at „formere sig som dyr" er for eksempel skældsord). Selv om vesterlændinge på nogle områder finder, at de bør kontrollere naturen og dyrene i den, er det på andre områder moralsk problematisk at intervenere i den, som for eksempel den offentlige debat om brugen af de nye reproduktionsteknologier vidner om (ibid.; Mosegaard 2005).

Referencen til menneskedyret $\mathrm{i}$ os, når det vedrører reproduktive behov og ønsker, er ikke overraskende, hvis man tænker på, at børn i generationer er blevet introduceret til forplantningens mysterier med hjælp fra dyr (Löfgren 1985; Yanagisako \& Delaney 
1995). Der var de velkendte historier om storke og hejrer, der fløj børnene ind (navlen er mærket efter næbbet, forstås, og netop storken optræder ofte som navn på eller ikon i moderne fertilitetsklinikker), og der var de forsigtige versioner med bier og blomster. Så var der landbobørnene, hvis seksualundervisning ofte bestod $i$, at de ved selvsyn kunne forvisse sig om de domestiske dyrs reproduktive fysiognomi og liv (Löfgren 1985). Også moderne børnebøger drager pædagogiske analogier mellem menneskers og dyrs reproduktion. I en af slagsen står der: „Næsten alle dyr laver også børn på den måde. De står som regel bare op. Men dyr boller kun for at få unger. Mennesker gør det mest, fordi de synes, det er dejligt at være sammen med en, man elsker på den måde“" (BechJessen 1987:14). Denne analogidragning lærer børn, at der eksisterer nogle fundamentale reproduktive ligheder mellem mennesker og dyr, men den pointerer også to afgørende forskelle: For det første, at der er forskel på menneskers og dyrs seksualitet, og for det andet, at mennesker i modsætning til dyr antages at kunne kontrollere såvel udfoldelsen som resultatet af deres reproduktive drifter. Så selv om ønsket om børn kan legitimeres med reference til en naturlig drift, mennesker deler med dyrene, så er ønskebarnet en moralsk fordring, der beror på ideen om, at børn er og bør være resultatet af individuel kontrol, valg og ansvarlig timing (Lundin 1996). Her adskiller mennesker sig fra dyrene. Dyreanalogier og dyremetaforer gør det muligt at formulere svære og „pinlige“ ting om mennesker. Men de fungerer kun i kraft af en samtidig markering af signifikante forskelle mellem mennesker og dyr (Tapper 1994:51).

Men analogier mellem mennesker og dyr har også virkekraft ud over det, der vedrører forplantning og reproduktion, for dyr indtager en ganske omfattende rolle i (ud)dannelse og opdragelse af børn (Löfgren 1985). Et væsentligt aspekt af menneskers slægtskab med dyr kan siges at bero på det utal af måder, hvorpå dyr indgår i socialiseringen af børn og derved bidrager til at transformere børn til voksne, fuldbefarne samfundsborgere. Der er således undersøgelser, der argumenterer for, at børns interaktion med levende dyr styrker deres sociale kompetencer og altså evnen til at udvikle omsorg og ansvar for andre mennesker (Belk 1996:122). Dyrs fremtrædende rolle i børns tilværelsestilegnelse kommer ikke kun til udtryk i antallet af kæledyr i børnefamilierne (jf. Danmarks Statistik 2000), men også i mængden af tøjdyr på børneværelserne og i overrepræsentationen af antropomorfiserede dyrekarakterer i børnelitteratur og børneudsendelser. Socialiseringen får gennem fremmedartede kæledyr og populære tv-udsendelser som Animal Planet også en global dimension.

Den britiske antropolog Mary Bouquet (1993) skriver, at børn lærer om socialt virksomme kategorier, værdier og verdens orden gennem de historier, de făr fortalt af voksne. Det er et tankevækkende perspektiv i betragtning af dyrenes manifeste tilstedeværelse i børnelitteratur: Børn lærer om signifikante aspekter af menneskers sociale liv i kraft af dyr. I bogen Reclaiming English Kinship (1993) benytter Bouquet Beatrix Potters klassiske børnefortællinger, også med dyr i hovedrollerne, som en minietnografi, der ikke blot udstiller engelske middelklasseforankrede forestillinger om slægtskab, familie- og hjemmeliv, køn og ,personhood“, men også ifølge Bouquet indikerer et nært slægtskab mellem Beatrix Potters dyrehistorier for børn, britisk stamtavletænkning og W.H.R. Rivers udtænkning af den genealogiske metode, der fik en signifikant betydning for antropologiske slægtskabsstudier (Bouquet 1993:185 ff.). Såvel i Beatrix Potters børnebøger som i mange moderne efterfølgere bruges dyrene til at formidle dominerende familiebilleder - af for eksempel kernefamilien. I sådanne repræsentationer af dyrelivet 
fortrænges dyrenes eventuelle naturlige, polygame liv, og i stedet „kernefamiliariseres“ de som farbjørn, morbjørn og lillebjørn eller hanepane, hønepøne og kyllerylle. Kernefamilien og familiemedlemmernes kønnede positioner og virkefelter naturaliseres og normsættes ved at blive portrætteret i dyreformat.

\section{Brandmænd og grise}

Men børnebøgerne står ikke altid mål med virkeligheden. For mange børn i Danmark er kernefamilien i hvert fald ikke en realitet. Og der er andre eksempler på, at analogien mellem mennesker og dyr har en begrænsning. Den svenske etnolog Orvar Löfgren (1985) indleder artiklen „Our Friends in Nature“ med en lille anekdote om en biltur med sin treårige søn. Undervejs bliver de pludselig overhalet af en række brandbiler. Sønnen følger dybt fascineret den dramatiske hændelse, indtil han pludselig vender sig mod sin far og med et skuffet udtryk udbryder: „Heyyy, de er ikke grise, de er mænd!" Löfgren indser, at hans søn er blevet overeksponeret for Richard Scarrys børnebøger, hvor grise er brandmænd og spiser bacon til morgenmad sammen med resten af grisefamilien.

Men der er også samfund, hvor de dyr-menneske-analogier, der giver mening i vestlige samfund, er totalt meningsforstyrrende. En af de mest underholdende beretninger herom er skrevet af den amerikanske antropolog David M. Schneider (1968). Den er citeret i flere bøger (Yanagisako \& Delaney 1995; Yanagisako 1995; Franklin 1997), netop fordi den tydeliggør dyr-menneske-analogiens kulturelle forankring, men også dens taget-forgivethed i vesteuropæisk slægtskabstænkning og antropologisk slægtskabsteori (se også Tjørnhøj-Thomsen 2003a). Oplevelsen var også med til at spore Schneider ind på en omfattende kritik af de klassiske slægtskabsstudier som etnocentriske (Schneider 1984).

Schneider beretter, at yap-folket ikke på nogen måde erkendte nogen sammenhæng mellem samleje og graviditet. De argumenterede blandt andet ved - over for Schneider - at udpege nogle særlig grimme kvinder, der havde fået børn på trods af deres udseende. En dag erfarede Schneider imidlertid, at yap-mændene kastrerede deres orner med den begrundelse, at de så blev federe. Yap vidste udmærket, at disse galte ikke kunne løbe en so. Denne oplysning fik Schneider til at udbryde, at alle jo havde fortalt ham, at samleje ikke gjorde kvinder gravide. Det er helt korrekt, replicerede yap-mændene, noget forundrede. Schneider fandt derefter anledning til nok engang (med stor etnografisk omhu) at gennemgå yaps version af den menneskelige reproduktion og grisenes ditto. Schneider skriver: „De var forundrede, og det samme var jeg. Vi forstod ikke hinanden. Jeg følte, jeg havde præsenteret dem for en række logisk inkonsistente udsagn, der skreg på forklaring“" (Schneider 1968:127-8, min oversættelse). Yap derimod kunne ikke få øje på inkonsistensen. Men efter længere tids diskussion gik der endelig en prås op for en af mændene. „Men mennesker er ikke grise,“ sagde han.

Men hvorfor kunne Schneider ikke se forskellen på mennesker og grise? Svaret er, at netop når det kommer til spørgsmålet om reproduktion, så antager de fleste amerikanerne og europæere at grise og mennesker grundlæggende er ens (Tsing 1995:117). Det vil sige, at de i lighed med Schneider tager for givet, at dyr og mennesker alle steder har den biologiske reproduktion til fælles og derfor på lignende måde er ,naturens skabninger“" (ibid.). Anekdoten tjener således som en afklædning af den skjulte, men 
dominerende euroamerikanske viden om et naturgivent slægtskab mellem mennesker og dyr. Ifølge yap var det kun idioter, der kunne finde på at sidestille grise og mennesker. De kunne - som Schneider formodentligt også ville kunne, hvis han havde tænkt på andre aspekter af mennesker og grise - nemt pege på masser af forskelle mellem mennesker og grise. Den afgørende forskel for dem i denne særlige sammenhæng var, at yapmennesker har forfædreånder, det har yap-grise ikke. Hverken brandmænd eller mennesker er altså grise. Schneiders ahaoplevelse og Löfgren-sønnikens skuffelse er momentvise afdækninger af en kulturbetinget grundforestilling om menneskers slægtskab med dyr, der dog langtfra har universel udbredelse.

\section{Animale fornærmelser}

At gå igennem fertilitetsbehandling er en psykisk, fysisk og socialt krævende proces, der inddrager læger, eksperter, procedurer og medikamenter. De barnløse betræder et ukendt og usikkert terræn, hvor der ikke altid kan gives entydige forklaringer på, hvorfor behandlingen ikke virker. Enkelte barnløse i min undersøgelse omtalte sig selv som „forsøgsdyr“. De drog dermed en analogi mellem deres egne oplevelser af fertilitetsbehandlingen og deres viden om forsøgsdyrs omdiskuterede livsvilkår. Forsøgsdyr er en kategori af dyr, der benyttes i forbindelse med medicinsk forskning og afprøvning af forskellige behandlingsmetoder og medikamenter til mennesker (eksempelvis medicin, solbeskyttelsesmidler, kosmetik, botox). ${ }^{5}$ Brugen af forsøgsdyr antager således, at der eksisterer et slægtskab mellem dyr og mennesker i form af biologisk lighed eller artslighed. Men flere dyreværnsforeninger anfægter denne formodede lighed mellem mennesker og dyr og betvivler derved, at det giver mening at overføre resultater fra dyreforsøg til mennesker. Modstanden mod dyreforsøg beror dermed ikke kun på, at opbevaring af og forsøg på dyr antages at påføre dyrene unødig lidelse, men også på, at dyr og mennesker reagerer fysiologisk og biokemisk forskelligt på medikamenter, hvorfor dyremodelstudier ikke kan oversættes til mennesker. ${ }^{6}$ Der er altså langtfra konsensus om karakteren af den biologiske lighed mellem mennesker og dyr, og det er heller ikke den lighed, de barnløse bringer i forgrunden, når de omtaler sig selv om forsøgsdyr. Så hvorfor gør de det? For at forstå analogien er det nødvendigt at se lidt nøjere på nogle træk ved de barnløses oplevelser af fertilitetsbehandling.

Når det gælder fertilitetsbehandling, er der ikke altid nogen forklaring på, hvorfor behandlingen ikke lykkes. Mange par overrumples af, at biomedicinsk viden og ekspertise ikke kan levere en entydig forklaring på eller afklaring af deres situation. Denne uafklarethed betyder, at også lægerne må prøve sig frem for at forsøge at få et godt resultat. Der kan være tale om at prøve et andet hormon, medikament eller en anden behandlingsform for at se, om det måske virker. Det betyder, at fertilitetsbehandling også ofte afstedkommer følelsen af at blive eksperimenteret på. Kroppen - og især kvindekroppen og dens reproduktive organer og substanser - er det centrale objekt for behandlingsforsøgene. Men mange kvinder føler, at dette fokus på kroppen har en tendens til at tilsidesætte dem som (hele) personer. Travlhed og rutiner på klinikken betyder, at det kan være svært at få tid til at stille spørgsmål og drøfte følelsesmæssige og psykologiske spørgsmål undervejs i behandlingsforløbet. Hertil kommer, at de barnløse i forbindelse med fertilitetsbehandling rent faktisk træder ind i et biomedicinsk felt, som er kendetegnet ved at 
være i hastig udvikling og genstand for omfattende forskningsmæssige og økonomiske interesser. ${ }^{7}$ Forsøgsdyrene optræder groft sagt i det samme biomedicinske felt som de barnløse, om end man vil finde dem i helt andre kontekster og lokaliteter. At omtale sig som forsøgsdyr er at give udtryk for kontroltab, objektgørelse, afhængighed og dehumanisering. Et ofte bemærket kendetegn ved dyr, og ikke mindst forsøgsdyr, er, at de er umælende. Når det drejer sig om kæledyr opleves denne ,stumhed“" ofte som betingelsesløs loyalitet (se Belk 1996; Reddy 1998), men i forsøgsdyrsanalogien fungerer selv samme umælenhed snarere som et billede på et tab af tale- og indsigelsesmulighed.

At omtale sig selv om forsøgsdyr kan ses som et eksempel på det, Edmund Leach kalder animal abuse (Leach 1968:27). I artiklen „Antropological Aspects of Language: Animal Categories and Verbal Abuse" definerer Leach animal abuse som en situation, hvor et menneske forurettes i kraft af en sammenligning med et dyr (Leach 1968:28). „Dit svin“ eller „,din so“ er således gode eksempler på animal forncermelse. Men også det at omtale sig selv som "forsøgsdyr" falder - om end det her benyttes til sætte ord på specifikke fertilitetsbehandlingserfaringer - ind under kategorien. Det, der interesserer Leach, er, hvorfor nogle dyrekategorier har stor effekt som skældsord (invektiver) og andre ikke; altså hvorfor (på engelsk og i en engelsk kontekst) ,you son of a bitch“ har en særlig fornærmelseseffekt, når ,you son of a kangaroo“ ikke har (op.cit.:29). Leachs hypotese er, at animal fornærmelse er forbundet med dyrets ,rituelle værdi“ (for eksempel om det er tabuiseret eller helligt). Det vil sige, at graden af den animale fornærmelseseffekt (eller smiger, eftersom sammenligningen med et specifikt dyr jo ikke altid er fornærmende) beror på, hvordan specifikke dyr klassificeres kulturelt. Der er således en nær association mellem animal fornærmelse (eller animal smiger) klassifikation af dyr og social interaktion mellem mennesker og dyr, og det er forbindelser af denne karakter, der er interessante her. Animal fornærmelse forbinder (specifikke) dyr eller dyrekendetegn med (specifikke) mennesker (Holmberg 1996). Mange af disse forbindelser er efterhånden blevet til faste kategorier, der er rykket over i det klassifikationssystem, vi benytter til at differentiere mennesker, selv om der bestandigt opstår nye (Hastrup 1999:172). Man kan være snu som en ræv og glat som en ål, opføre sig som en gris og - hvis man fremturer med det - et svin, man kan være smidig som en kat, spise som en fugl og være som en elefant i en glasbutik samt have en kyllingehjerne. Det er imidlertid ikke hverken socialt eller moralsk ligegyldigt, hvilken slags dyr man på denne måde siges at ligne.

Specifikke menneskers relationer til dyr kan omvendt også påkalde sig omgivelsernes identitetstilskrivning og stigmatisering af mennesker - og dyr. Jeg blev for nylig bekendt med to nye kategorier af hunde: ,psykopatpuddel“ og ,taberpony“. Sidstnævnte er efter sigende en meget stor hund i følgeskab med en ,social taber“, mens psykopatpuddel er en grum, aggressiv og bidelysten hund, hvis adfærd antages at være det direkte resultat af en psykopatisk ejer. Man kunne selvfølgelig argumentere for, at der her er tale om human forncermelse, eftersom det er dyret, der forulempes i kraft af sammenligningen med mennesker. Men slutresultatet er det samme. Specifikke menneskers særegne interaktion og forbundethed med specifikke dyr mobiliseres som en social differentieringsmekanisme.

Men forbundetheden og interaktionen med dyr har endnu en social dimension. Der er mennesker, der beretter, at de er „til hunde“, og der er dem, der er mere „til katte“. Der er også i stigende grad mennesker, der er til kulturelt set fremmede dyr som slanger, kamæleoner og fugleedderkopper. At vare til et bestemt dyr er ikke kun en markering 
af et særligt tilhørsforhold til en bestemt kategori af dyr, men også til en bestemt kategori af mennesker (for eksempel en form for forestillet fællesskab med alle dem, der er til katte) og således tæt forbundet med selvforståelse og selvfremstilling. Det er fristende her at drage paralleller til totemistisk tankegang (jf. Lévi-Strauss 1991), hvor forskelle mellem grupper af mennesker artikuleres i kraft af deres fælles forbundethed med et specifikt dyr (her: kæledyret som totem) og derved fungerer som et organiseringsprincip for det sociale liv.

Det er vigtigt at understrege, at forholdet mellem klassifikation af og interaktion med dyr ikke er entydigt eller stabilt. Hvad der defineres som ,grusom“ eller ,human“ behandling af dyr afhænger, som antropologen Kaoru Fukuda viser i sin sammenlignende analyse af rævejagt og kæledyr i Storbritannien (1997), af den specifikke kontekst omkring menneske-dyr-interaktionen. For nogle af de britiske bønder klassificeres rævene som skadedyr. De er hønsetyve, hvilket i nogen grad legitimerer jagten på dem. Kukuda argumenterer imidlertid for, at den egentlige - men knap så moralsk gangbare - begrundelse for at deltage i rævejagt er, at deltagerne synes, det er sjovt. Rævejagt er altså en social aktivitet, der er forbundet med ,action“, lyst og spænding (op.cit.:2-3). Jagt bliver derved, som en særlig dyr-menneske-interaktionsform, samtidig rammen om særlige (maskuline og klassebetingede) samværsformer og fællesskaber, i øvrigt med jagthundene som betydningsfulde aktører.

Der er altså ikke nødvendigvis nogen modsætning mellem at gå på kaninjagt i baghaven og samtidig have kaniner som kæledyr i et bur i forhaven. Det er et spørgsmål om formål, perspektiv og situation.

\section{Få jer en hund}

Vi har fået en hund, to katte og en kanariefugl, hvad vil de nu foreslå?

Jeg hører nok også til dem - når jeg ser i bakspejlet - det var noget med, at det hele skulle være villa, Volvo og vovse ...

De barnløse mænd og kvinder i min undersøgelse fik ofte mange gode råd fra familie og venner. Et af de mest omtalte råd var, at de skulle anskaffe sig et kæledyr for ,at tænke på noget andet“. Det er en udbredt forestilling, at man kan tænke „,for meget“ på at få børn og derved hæmme reproduktionen. At tænke på noget andet ved at omgive sig med et kæledyr skulle altså ifølge denne forståelsesramme have en fordelagtig effekt på det reproduktive flow. De fleste barnløse fandt umiddelbart disse råd latterlige, absurde og fornærmende, blandt andet fordi rådene også udpegede dem som psykisk og tankemæssigt „,besat“ af børn og dermed også som selvforskyldte i deres barnløshed. Samtidig med at få-jer-en-hund-rådet blev mødt med irritation, forblev det ikke nødvendigvis uprøvet, som det indledende citat til dette afsnit indikerer. Der var altså masser af kæledyr - også i de barnløses hjem. Mange lagde da heller ikke skjul på, at et kæledyr eller to kunne være en trøst i det uønskede barneløse liv. Få-jer-en-hundrådet underforstår nemlig også et andet centralt forhold, nemlig at kæledyret kan fungere som substitut for et eller flere børn og altså udfylde det relationelle, emotionelle og fysiske tomrum, som fraværet af ønskebarnet bevirker (Tjørnhøj-Thomsen 1999). 
Det andet citat, der indleder dette afsnit, er en kvindes tilbageblik på ønsket om børn som led i en forventning om et liv med villa, Volvo og vovse, en kliché for et almindeligt eller normaldansk middelklassefamilieliv (som hun imidlertid aldrig fik indfriet på grund af infertiliteten). Her har vovsen også for længst fået en plads.

De barnløses fortællinger peger på et mere generelt socialt fænomen, nemlig at kæledyr er blevet en integreret del af det moderne familieliv. En opgørelse fra Danmarks Statistik viser, at 880.000 familier i Danmark - og med til familiedefinitionen hører også samlevende par uden børn - holder et eller flere kæledyr. De fleste familier, 450.000, holder en eller flere hunde, $550.000 \mathrm{i}$ alt, mens 370.000 familier deles om ca. 650.000 katte. Danmarks Statistik konstaterer, at der en ,udpræget sammenhæng mellem kæledyr og familier med børn og endda i en sådan grad, at stigende børnetal også medfører stigende grad af kæledyr i familien“ (Nyt fra Danmarks Statistik 2000). Kæledyrsstatistikken matcher de mange nye bøger på kæledyrs- og hundeopdragelsesområdet. I en af bøgerne understreges det, at det er vigtigt at gøre sig helt klart, „hvilken slags hund der passer ind i din og din families hverdag" (Jarnberg 2005:26). Budskabet er, at familiehunden må matche den enkelte families sociale særegenhed og hverdagsliv.

Selv om kæledyr på ingen måde er et historisk nyt eller entydigt vestligt fænomen, ${ }^{8}$ er der tale om en signifikant ekspansion i kæledyr og kæledyrsrelaterede aktiviteter og forbrugsmønstre i vestlige samfund i det 20. århundrede. At kæle med en hund skulle således have en blodtrykssænkende virkning, og såkaldte „therapets“ (altså terapeutiske kæledyr) kan hjælpe depressive patienter og fysisk og psykisk handicappede børn (Fukuda 1997:4). En antropologisk undersøgelse af et kæledyrsterapiprogram for ældre på plejehjem viste, at det at få besøg af dyr gav beboerne mange gode stunder, blandt andet fordi dyrenes nærvær fremkaldte nuancerede erindringer om kæledyr, de ældre selv havde haft, og derigennem også om de ældres tidligere familieliv og hjem. Kæledyr har således også fået plads i familiefortællingerne (Savishinsky 1985).

Kæledyrenes fremkomst er et resultat af en følelsesmæssig nyorientering til dyr, som ofte kobles sammen med den stigende urbanisering og med nye industrielle produktionsvilkår i det 19. århundrede. Der skete en udgrænsning af dyr fra det menneskelige erfaringsdomæne, og færre og færre mennesker fik direkte og konkrete erfaringer med dyr (Tapper 1994:48; Macfarlane 1987:79). ${ }^{9}$ Til gengæld, lyder argumentet, involverede de sig i kæledyr og dyreværn, altså i menneskers moralske forpligtelse over for dyr og dyrs rettigheder (Kete 1994). Antropologen Alan Macfarlane påpeger, at det at holde kæledyr er associeret med et lavt fødselstal, en stor følelsesmæssig investering i det enkelte barn og et moderne ,atomistisk“ slægtskabssystem, hvor børn og kæledyr er blevet en ,luksusvare“. Kæledyrenes fremkomst er således også forbundet med en ny kernefamilieform, som i første omgang var forankret i den borgerlige kultur, der opstod i det 19. århundrede. Borgerskabet markerede sin særegenhed og klasse (og tilhørsforhold til moderniteten) i kraft af sine kæledyr. At holde kæledyr blev en måde at distancere sig fra såvel bønders og arbejderes som adelens brutale måde at interagere med dyr på (Löfgren 1985; Kete 1994). ${ }^{10}$ Samtidig med at borgerlige ideer om selvdisciplinering og civiliseret opførsel bestod i en fornægtelse af det dyriske i mennesket, tog borgerskabet en særlig kategori af dyr med ind i hjemmene: kæledyrene (Löfgren 1985:198).

Etnografiske observationer uden for den specifikke barnløse kontekst i Danmark viser, at dyr i stigende grad er blevet integreret i familiens socialitet og ritualer. Kæledyrene får jule- og fødselsdagsgaver, legetøj, klæder og hotelophold; de holder fødselsdag, 
optræder på familiefotos, de begraves og mindes, og de bidrager aktivt til familielivets harmoniske og konfliktfyldte stunder. Hverdagslivet byder også på hundehidkaldemåder a la „Kom så hen til mor“ eller „Ja, du er fars hund, er du, go” hund“, ligesom en „hundebedste“ er dukket op som en ny kategori af bedsteforældre (jf. Reddy 1998). En „,hundebedste" er et menneske, der fungerer som bedstemor for sine menneskebørns hunde. Altså passer hunden, når dens „,forældre“ ikke kan, og i den forbindelse forkæler den lidt for meget og dermed praktiserer en særlig velkendt bedsteforældre-børnebørnforbundethed, der blandt andet består i at suspendere de gængse spise- og samværsregler. Hunde er at ligne med børn. Men der er igen en afgørende forskel. For selv om hvalpe bliver fuldvoksne hunde, så bliver de ikke for alvor voksne som mennesker. Kete påpeger, at infantilisering og kontrol var nogle hovedtræk i det parisiske borgerskabs kæledyrskultur i det 19. århundrede. Kæledyrene levede i en „evig barndom“ og skulle opdrages som børn, ,,venligt, men bestemt“ (Kete 1994:82). En gammel hund bliver således allerhøjst en ,gammel dreng“, men aldrig en mand.

Analogidragning mellem børn og kæledyr er således under alle omstændigheder kulturelt ambivalent. Det kommer for eksempel til udtryk i artiklens indledende citat: „Nu må du ikke grine af mig“, siger kvinden, før hun forklarer, hvordan den nyerhvervede hunds tilstedeværelse har ændret hendes ideer om sig selv, sit arbejde og eventuelle børn. Hun synes selv, at det er lidt komisk, hvad en hund kan afstedkomme. En anden kvinde fortalte, at hun så gerne ville have en hund. Men hun havde afholdt sig fra at anskaffe en: „Jeg vil ikke have, at folk tænker, at nu fik hun en hund, fordi hun ikke kan få børn“, som hun udtrykte det.

\section{Slægtskab med Sille}

Under mit feltarbejde besøgte jeg et par, der længe havde forsøgt at få børn og havde gennemgået adskillige resultatløse behandlingsforsøg. For nylig var de dog begyndt at overveje adoption, og deres nyanskaffede hund spillede en ikke helt ubetydelig rolle i disse overvejelser. Jeg mødte hunden i entreen sammen med dens ejere. Det hører med til historien, at denne hund havde et bemærkelsesværdigt udseende. Dens ejere mente selv, at den var meget grim. Den var en udefinerlig, noget uproportioneret blanding af en puddel og en gravhund. Farven var brækket hvid med et lidt gråligt-pink skær, der - ikke ualmindeligt for lyse og letbehårede hunde - bliver mørkere omkring øje- og snudeparti. Det var en utrolig sød hund, der tog del i den sociale interaktion og særlige form for deltagerobservation, som interviews også er. Den placerede sig, som det er almindeligt for mange kæledyr, i sofaen og påkaldte sig iblandt opmærksomhed og kommentarer ved at bevæge sig rundt, lægge hovedet $i$ antropologens skød, snuse-bide lidt $\mathrm{i}$ båndoptager, ledninger og mikrofon, hoppe op og ned, dreje rundt $\mathrm{i}$ koncentriske cirkler, klø og loppe sig. Vi mennesker snakkede længe om savnet af børn og mislykkede behandlingsforsøg.

Kvinden fortalte, at hun nu var begyndt at overveje adoption. Men hun havde denne lille tvivl: Ville det være muligt at elske et fremmed barn? Sådanne overvejelser og tvivl er almindelige. Alle parrene i min undersøgelse håbede på og forsøgte i første omgang at få deres ,eget“ barn, altså et barn, begge parter var genetisk forbundet til, og derved blive i stand til at etablere, hvad der kulturelt og socialt anses som en rigtig familie. 
Men det var et ønske, mange også måtte lægge på hylden. De fleste var imidlertid overbeviste om, at de ville kunne elske et adoptivbarn, „som var det deres eget“. Men de var usikre på de relationelle implikationer af, at barnet ikke var genetisk forbundet til dem. Ville det skabe problemer for barnet? Ville det få identitetsproblemer? Ville barnet for eksempel engang i et pubertetsopgør råbe: „Og du er ikke engang min rigtige far!"? De potentielle forældres overbevisning om, at de ville kunne elske et hvilket som helst barn, kunne altså ikke helt overskygge fornemmelsen af en relationel skrøbelighed, hvis relationen ikke blev genetisk. Kvinden fortalte:

Men sidste år fik vi så Sille [hunden]. Og efter en uge kunne vi ikke undvære hende. Så vi talte om det på denne her måde. Når det er muligt at elske en hund så meget, så vil vi også kunne elske et adoptivbarn. Og jeg har jo ikke født Sille [latter]. Men det er den der følelse af at føle sig ansvarlig for nogen. Nogen, der er afhængig af dig. I dag tvivler jeg slet ikke på, at jeg kan elske et andet barn - overhovedet ikke.

Denne case og den direkte analogidragning mellem adoptivbarn og en hund fremkalder ofte en vis moralsk utilpashed eller usikkerhed hos dem, der hører om den. Ligesom kvinden, der fortæller, selv tøver lidt ved sammenligningen ved at anlægge en ironisk distance til den. For der er så åbenlyst en forskel mellem hunde og adoptivbørn, men der er også nogle ligheder, som her bliver afgørende. For at udfolde dette og det efterfølgende eksempel er der behov at se lidt nøjere på et par begreber, der er dukket op i en række nyere slægtskabsstudier: forbundethed (Carsten 2000) og „kinning“, eller som jeg har valgt at oversætte det, ,beslægtelse“ (Howell 2001).

\section{Forbundethed og beslægtelse}

For nogle år siden introducerede den britiske antropolog Janet Carsten begrebet forbundethed (Carsten 1997, 2000). Hensigten var at undslippe den analytiske opposition mellem biologisk og socialt, der har været underforstået i mange slægtskabsstudier og derved også suspendere og nuancere de grundantagelser, som termerne social og biologisk rummer (Carsten 2000:4). I stedet for at arbejde ud fra en a priori-antagelse om, hvad slægtskab er, bør antropologer ifølge Carsten udforske, hvordan de mennesker, de undersøger, selv definerer, praktiserer, føler og omtaler forbundethed, og dermed nuancere og udvide forståelsen af slægtskab. Forbundethed er altså ikke noget i sig selv, men en måde at spørge ind til og specificere relationers eller intersubjektive forholds særlige tilblivelse og beskaffenhed på; en analytisk position, hvorfra man kan undersøge, hvorledes specifikke former for forbundethed mobiliseres i forskellige situationer og af forskellige aktører (Tjørnhøj-Thomsen 2004). ${ }^{11}$ Ved at spørge ind til forståelser af forbundethed bliver det for eksempel muligt at nuancere betydningen af ,eget barn“ og „rigtig familie“, som de ufrivilligt barnløse i udgangspunktet ønsker at få og være. Endelig giver det også mulighed for at undersøge, hvordan ikke-menneskelige ,andre“, altså dyr og ting, ,beslægtes“(Howell 2001) og inkorporeres i den menneskelige familie og i slægtskab. Signe Howells „beslægtelsesbegreb“ vedrører netop de forskellige strategier, gennem hvilke norske adoptivforældre søger at inkorporere adoptivbørn i den dominerende familiemodel. 
Den egentlige pointe i eksemplet med hunden Sille er, at tilstedeværelsen af hunden og den daglige interaktion med den har genereret stærke følelser af ansvar, kærlighed, gensidig afhængighed, sjov og omsorg. Alle betegner de måder at tænke, føle og praktisere forbundethed på, der minder om børn, familieliv og slægtskab, men som så åbenlyst ikke har at gøre med hverken genetisk eller gestationel forbundethed, ${ }^{12}$ som begge er aspekter af forbundethed, der tidligere har fyldt meget i parrets overvejelser om børn. Sille er i sandhed hverken undfanget eller født af mennesker. Men det daglige samvær med hunden og den særlige forbundethed, det har skabt, har kvalificeret og givet substans til den skrøbelige følelse, at det er muligt at elske og beslægte - altså inkorporere og integrere - et adoptivbarn, ,som var det ens eget“, gennem hverdagslivets samvær og nærvær. Silles tilstedeværelse åbner dermed op for den erkendelse, at slægtskab kan etableres på andre måder end ved at få et eget barn. Men slægtskabet med dyr har også en begrænsning, og det handler den efterfølgende case om.

\section{Et navn og en person}

Et af parrene i min undersøgelse havde forsøgt at få børn i mange år. Det lykkedes til sidst. Men forinden havde de fortalt mig, at hvis de ikke fik børn, så ville de bruge noget mere tid på deres katte: to store og langhårede racekatte. Parret lagde ikke skjul på, at de havde betragtet kattene som „,deres børn“ og brugt en del tid på dem og på at tage til forskellige katteudstillinger. Men så lykkedes det efter mange mislykkede behandlingsforsøg, adskillige aborter og angstfulde graviditeter at få et barn. Det havde været svært at fatte, at det var lykkedes.

En aften fortæller Signe om den lille hændelse, der endelig fik hende overbevist om, at $n u$ havde hun et barn, og at det gjorde en forskel. Hun havde været til en nær vens begravelse. Vennen havde aldrig fået børn, og det var ikke klart, om han overhovedet havde ønsket sig nogen. Efter begravelsen gik Signe op for at se på de mange kranse og blomster, der lå på kirkegulvet foran kisten. Et bånd på en af de største kranse fangede hendes opmærksomhed. Der stod „Fra Johanne og børnene“. Johanne var afdødes hustru, børnene var - vidste Signe - deres to hunde. Da blev det klart for hende, at hvis det var hende, der var død, ville der have stået et personnavn, nemlig navnet på hendes datter. Det blev i dette øjeblik eksplicit, at selv om dyr kan kompensere for børn i hverdagen, så kan de ikke efterfølge eller reproducere en, som børn kan. De kan ikke leve op til forventninger om at besøge en, når man bliver gammel. Netop tanker om at ,efterlade sig noget“", „fortsætte slægten“, ,gøre sin mor til bedstemor“ eller „,blive tænkt på“ eller „husket“ er nogle af de centrale betydninger af børn og slægtskab, der også kommer til udtryk blandt de barnløse (Tjørnhøj-Thomsen 1999:97). Nu kunne der imidlertid sagtens have stået to personnavne på båndet, for kæledyr får i højere og højere grad menneskelige navne. Navne som Anton, Oliver, Emma og Mille er blandt de mest populære, ikke kun til børn, men også til kæledyr (Kentorp 2005). Men det er ikke pointen i det ovenstående eksempel.

Pointen er, at hunde eller kæledyr ikke kan forbinde én i tid, det kan kun personer. Det er i den forbindelse ikke afgørende, at denne person er ens ,eget“" genetisk forbundne barn. For selv om de fleste af de barnløse i min undersøgelse primært ønsker og tænker reproduktion som et genetisk anliggende, og som nævnt ønsker sig deres „eget“ barn, 
så må de, der ikke kan få egne børn, søge at omdefinere reproduktion til også at være et spørgsmål om at videreføre om ikke gener, så livsværdier og holdninger, som også den forrige case viste. Denne forståelse af videreførelse eller reproduktion insisterer på den forbundethed, der skabes i kraft af hverdagslivets interaktion, samvær og omsorg. Den kan forvaltes af børn - genetiske eller ej - men altså ikke af kæledyr. Det var det, der blev tydeligt for Signe ved vennens begravelse. Dyr kan muligvis have personlighed, men de er ikke personer, og de bliver ikke voksne, som børn gør det.

Eksemplerne viser, at samtidig med at kæledyr og børn er aktører i familie- og hjemmeliv og derved i hverdagslivets mangfoldige slægtskabspraksisser, har den nære analogi mellem børn og kæledyr også en begrænsning. Kæledyr kan ikke forbinde én i tid. De kan ikke reproducere eller udødeliggøre mennesker hverken i den dominerende genetiske betydning eller i den sociale. Selv om der kan knyttes langvarige og stærke følelsesmæssige slægtskabsbånd mellem mennesker og dyr, så giver det ikke i vesteuropæisk sammenhæng mening at indføje dyr i genealogien. Det er muligt, at hunden kommer til at ligne sin ejer, men den kan ikke, som børn, videreføre personlig identitet. Analogiens begrænsning kommer også til udtryk i en anden empirisk kontekst: mindetavler på internettet.

Internettet er som bekendt blevet et nyt og anderledes socialt rum for erfaringsudvekslinger, skabelse af fællesskab og memoralisme og dermed også et relevant etnografisk rum for udforskning af de mangfoldige former for forbundethed, mennesker føler og praktiserer. Under forarbejdet til denne artikel blev jeg opmærksom på en diskussion på en internetmindeside, www.mindet.dk. Det er en mindeside, hvor mennesker, der har mistet en nær slægtning, kan oprette en mindeside og tænde lys for afdøde familiemedlemmer. På hjemmesiden er der også mulighed for at skrive og svare på forskellige indlæg. Et af indlæggene kritiserede, at der nu også var dukket mindesider og tændte lys for dyr op på www.mindet.dk. Vedkommende fandt, at hjemmesiden burde være forbeholdt mennesker. Det er, stod der i indlægget, „forstyrrende“, „mærkeligt“ og „forkert" at læse om tændte lys for en hund, når der er flere forældre, der har mistet deres små børn. Hjemmesidens administrator svarede, at han havde fået en del henvendelser om „dyr-menneske-problematikken“, som han betegnede det, og at han havde stor forståelse for de følelser, som en ,sammenblanding af mennesker og dyr kan afstedkomme“". Administratoren havde derfor besluttet at købe domænet www.dyremindet.dk, hvor der nu er etableret en særskilt plads til dyreminderne.

Forbundetheden med kæledyr er altså af en beskaffenhed, der bevirker, at tabet af dem afstedkommer følelser og mindebehov, der ligner dem, der er forbundet med tabet af et familiemedlem. Men at slå tabet af et kæledyr i hartkorn med tabet af et barn afstedkommer også et moralsk ubehag. Kæledyr og børn kan ikke sidestilles.

\section{Slægtskabets begrænsning}

At tale om menneskers slægtskab med dyr vil for de fleste mennesker i en vesteuropæisk kontekst afstedkomme et vist forbehold, der beror på en grundlæggende ambivalens i menneskers forhold til dyr, som er blevet tydelig i eksemplerne ovenfor. På den ene side vil de fleste anerkende, at mennesker er beslægtede med dyr, i den forstand at dyr og mennesker har noget til fælles biologisk og forplantningsmæssigt set, og mange vil 
også i større eller mindre omfang gå med til at betragte kæledyr som et familiemedlem. På den anden side er der også som vist klare forskelle mellem mennesker og dyr.

Forbeholdet skal blandt andet forstås i forhold til nogle dominerende og særegne karaktertræk ved vesteuropæisk eller ,euroamerikansk“ slægtskab (Strathern 1992b). I det epokegørende værk American Kinship. A Cultural Account (1980) karakteriserer den nu afdøde amerikanske antropolog David M. Schneider amerikansk slægtskab som en kombination af elementer fra to overordnede kulturelle ordner: naturens orden og lovens orden. Naturens orden vedrører de relationer, der er baseret på fælles biogenetisk substans, og som konstitueres i den heteroseksuelle forplantning, altså i samlejet. Disse relationer forestilles at være varige og ufravælgelige og givne ved fødslen. At være forbundet i kraft af naturens orden implicerer også ifølge denne tankemodel fælles oprindelse og identitet. Ideen om familieskabets varighed og ufravælgelighed kom ofte til udtryk hos de barnløse i min undersøgelse. Når de overvejede, hvad familie var eller burde være, så talte de om familien som nogen, man har „uanset hvad“, og „,som altid vil være der“ og som en særlig hjemlig kontekst, hvor „,man kan være sig selv“. Disse forventninger til familien stod dog ikke altid mål med de barnløses oplevelser af, hvordan deres familie rent faktisk opførte sig, når de skulle håndtere deres barnløse slægtninge. De store forhåbninger om familiens ubetingede støtte og bærekraft blev ganske vist indfriet i nogle situationer, men ledsagedes også ofte af ballader og brud. Familielivet udfoldes i spændingsfeltet mellem stærke ideer om evig forbundethed, varig solidaritet og rummelighed og mere dagligdags konflikter og problemer (se Gillis 1996; Mosegaard 2005).

I modsætning til (forestillingen om) de ubrydelige naturlige relationer kan relationer baseret på lovens orden - og her tænkte Schneider for eksempel på ægteskab - brydes og omgøres. En ekskone eller eksmand er en mulig og hyppig kategori, mens en eksdatter i forhold til denne tankemodel er en umulighed.

Dyr passer ikke helt ind i denne model for slægtskab. I en vesteuropæisk kontekst gifter vi os ikke med dyr. Der figurerer heller ikke dyr på stamtræet og i genealogien, for mennesker er ikke blodsbeslægtede med dyr, selv om de stammer fra dyr (som de fleste vesteuropæere har lært fra Darwins teori om arternes oprindelse; teorien var i øvrigt voldsomt omstridt på Darwins tid, fordi den antastede den kristne skabelsesberetning). Der er derfor også en udbredt grundaccept af, at slægtskabet (eller den biologiske lighed) med nogle dyr, for eksempel aber og primater, er mere naert end slægtskabet med kongeørne og øgler (jf. Paparagoufali 1996). Selv om sex med dyr forekommer og er moralsk omstridt, så foregår sex med dyr ikke med henblik på reproduktion. Dyr og mennesker får ikke afkom sammen. Her går et grænseskel, der ikke kan overskrides (endnu) uden at afstedkomme kulturel og social uorden med forestillinger om monstrøse skabninger i kølvandet. Tanken om substansforbundethed med dyr er kulturelt problematisk, som den svenske etnolog Susanne Lundin (1999) viser i sit studie af xenotransplantation (transplantation af dyreorganer, -væv eller -celler til alvorligt syge mennesker $\mathrm{i}$ håb om at kurere dem). For nogle af Lundins informanter fremmaner xenotransplantation moralsk usikkerhed og tanker om, hvorvidt de for eksempel vil inkorporere træk fra dyredonoren. Mens andre søger at håndtere transplantationen ved at forestille sig dyr og mennesker forenet $i$ et større og mere omfattende naturligt udvekslingsfællesskab. Lundins undersøgelse er et godt eksempel på, hvordan forskelle og ligheder med dyr mobiliseres forskelligt i individuelle håndteringer af 
xenotransplantation. Kulturelt betingede grænsemarkeringer mellem dyr og menneske er under alle omstændigheder blevet udfordret af bioteknologiske praksisser de seneste to-tre årtier. Disse praksisser har afstedkommet en bekymring for, om det unikt menneskelige kan opretholdes. Men de har også, påpeger den græske antropolog Eleni Paparagoufali, afstedkommet både en reklassifikation af grænserne mellem dyr og menneske og en reevaluering af dyr-menneske-relationer (Paparagoufali 1996).

\section{Dyr mellem mennesker}

Artiklen sidste tema vedrører de mere omfattende sociale fællesskaber, der både etableres omkring - og trues af kæledyrene. Dyr forbinder, som også børn, deres forældre/ejere med større og mere omfattende sociale fællesskaber, der udfolder sig omkring aktiviteter som agilitytræning, jagt, udstillinger, avlsarbejde, luftning mv. Der er tale om fællesskaber, der tager afsæt i, men samtidig overskrider familien og hjemmet (jf. TjørnhøjThomsen 1999; Reddy 1998:155). Kæledyrsejere bliver (som også forældre) uvægerlig integreret i mere omfattende forbrugsfællesskaber. Der bruges mange sociale og økonomiske ressourcer på kæledyrenes socialisering, trimning, udklædning og ernæring (Nicolaisen 1996). Markedsføring og forbrug af dyremad, dyrelegetøj, dyretøj, dyrehoteller og dyrebagerier, dyrehospitaler og dyrebegravelser, -kremeringer og -kirkegårde er tillige eksploderet de seneste årtier. Kæledyrene er således ikke kun familiemedlemmer, men også aktører i og anledning til etablering af sociale fællesskaber, der rækker ud over familien.

Men kæledyr er også stadig dyr. Man behøver ikke bevæge sig ret meget rundt i en dansk sammenhæng, før kæledyrenes ambivalente status som både familiemedlemmer og dyr træder frem som et konfliktuelt aspekt af hverdagslivet. I det landlige område, hvor jeg bor, er der således masser af eksempler på, hvorledes menneskers nære forbundethed til deres kæledyr kommer på kollisionskurs med de aspekter af forbundethed, der kendetegner et godt naboskab. ${ }^{13}$ Ved nøjere og systematisk eftertanke kan jeg konstatere, at de fleste nabokonflikter i min egn er forankret i følgende forhold: menneskers stærke følelsesmæssige forbundethed med deres kæledyr og kæledyrenes (naturlige) animale disponering for at krydse territoriale matrikelgrænser og for eksempel lægge ekskrementer i nabohaven, angribe naboens børn eller andre dyr eller ødelægge mænds jagtoplevelse ved selv at jage vildtet. Anmodninger om at tøjre hunden (og det er ofte hunde), etablere en hundegård eller på andre måde kontrollere og/eller begrænse dyrets aktionsradius skaber ofte bitre reaktioner. Det, der er på spil, er en uvelkommen intervention i den særlige forbundethed, familier etablerer med deres kæledyr, hvorved kritikken af kæledyret (og af dyrets personlighed) uvægerlig kommer til at fremstå som en kritik af dens ejers og en indgriben i privatlivets fred (jf. Reddy 1998:136).

\section{Slægtskab med dyr}

I denne artikel har jeg med afsæt i de barnløses brug af dyr i deres fortællinger om barnløshed belyst og diskuteret forskelligartede forbindelser og former for forbundethed mellem mennesker og dyr. De barnløse benytter dyreanalogier og altså viden og 
antagelser om ligheder mellem dyr og mennesker som måder at tænke på, naturalisere og legitimere deres ønske om og længsel efter børn på og til at udtrykke erfaringer og oplevelser af behandlingsforløbet. De barnløses konkrete hverdagssamvær med deres kæledyr åbner tillige op for at fremtænke og betone andre aspekter af familieliv og slægtskab end dem, der vedrører biologisk forplantning og genetisk forbundethed. Som en måde at tænke med dyr på fungerer analogidragning altså som en mobilisering af kulturforankrede ligheder og forskelle mellem dyr og mennesker, der er indlejret $\mathrm{i}$ konkrete dyr-menneske-interaktioner, og hvis betydning og effekt er betinget af situation og kontekst. Animale fornærmelser og/eller lovprisninger og menneskers affinitet til specifikke dyr kan mobiliseres som sociale differentieringsmarkeringer og dermed også som markeringer af menneskeligt fællesskab og identitet. De måder, hvorpå dyr indgår i barnløses fortællinger, er blot specifikke versioner af en mere generel historisk funderet og nutidigt forstærket tendens til på den ene side at beslægte dyr ved at inkorporere dem i menneskelige slægts- og fællesskaber og på den anden side lære mennesker om slægt- og fællesskab i kraft af dyrefortællinger og social interaktion med dyr.

Analogidragningen mellem mennesker og dyr er imidlertid grundlæggende ambivalent, og slægtskabet mellem mennesker og dyr har som vist klare begrænsninger. Mennesker gifter sig ikke med dyr, og dyr kan ikke reproducere mennesker hverken i en biologisk eller social betydning. De kan ikke skabe livsprogression og forbundethed i tid, som menneskebørn kan. Ikke desto mindre har dyr en ganske central placering $\mathrm{i}$ vestlige menneskers tankeverdener, sociale liv og selvforståelse. Det er derfor heller ikke overraskende, at dyr-menneske-forholdet sniger sig ind i grundlaget for antropologiske slægtskabsstudier. W.H.R. Rivers lod sig inspirere af britisk stamtavletænkning, da han udviklede den genealogiske metode. Og David M. Schneider blev, da han opdagede, at mennesker ikke er grise, ansporet til en kritik af slægtskabsstudiernes indbyggede etnocentrisme, der universaliserede det, dyr og mennesker antages at have til fælles i en vesteuropæisk tankeverden: den biologiske forplantning.

\section{Noter}

1. Feltarbejdet, der ligger til grund for undersøgelsen, blev udført i Danmark 1995-98 og foregik blandt grupper af barnløse, på fertilitetsklinikker, konferencer, høringer, adoptionskurser mv. (Tjørnhøj-Thomsen 1999, 2003a, 200b, 2004).

2. Analogiens forskel beror på, at samtidig med at der eksisterer en forbindelse - en lighed - mellem to fænomener, kan hver af disse også forbindes til helt andre domæner. Dette forhold betegner Strathern merografiske relationer (Strathern 1992a:73).

3. Naturalisering fungerer ikke kun som strategi til at legitimere ønsket om børn, det er også samtidig en måde at legitimere fertilitetsbehandlingen på og dermed berettige en form for medicinsk intervention, som endnu af mange betragtes som unaturlig og dermed også potentielt umoralsk og farlig.

4. Sådan er det for eksempel med de domestiske dyr, som er betegnelsen for forskellige brugs- og kæledyr. Vesterlændinge forventer, at domestiske dyr opfører sig som mennesker på kulturelt ,,genkendelige“ måder (Tsing 1995:115). Dyrene forventes at etablere sociale relationer med mennesker (og altså arbejde med og for dem, modtage omsorg mv.). Men de forventes også at opføre sig naturligt og indgå indbyrdes frugtbare slægtskabsrelationer, så de kan reproducere sig og derved være til nytte for mennesker (op.cit.:116). „De domestiske dyr er på en og samme tid formet af, men undslipper også de kulturelle modeller for det handlepotentiale (agency), mennesker påtvinger dem“"(op.cit.:115), skriver Tsing og peger her på en mere generel ambivalens i menneskers slægtskab med dyr. 
5. Forsøgsdyrenes Værn, www.forsoegsdyrenes-vaern.dk.

6. Se referat af tale afholdt af den engelske forsker og modstander af dyreforsøg Robert Sharp. Komiteen mod Dyreforsøg, www.dyreret.dk.

7. Det hører med til fortællingen, at flere barnløse i min undersøgelse blev spurgt (i forbindelse med deres fertilitetsbehandling), om de ville indgå i specifikke forskningsprojekter.

8. I bogen Kinship with Monkeys viser Loretta A. Cormier (2003), hvordan guajá-folket i Amazonas holder aber som kæledyr. Guajá jager også aber for at spise dem. Men kvinderne kan beslutte, om de abeunger, der har mistet deres mødre under jagten, skal holdes som kæleaber (,,pet-monkeys“). Som kæleaber integreres de i guajás slægtskabssystem som kvindernes børn (Cormier 2003:114). Selv om skovens levende væsener generelt betragtes som slægtninge, bliver kæleaberne inkorporeret mere direkte i slægtskab på husholdsniveau, og omsorgen for aberne står i skarp kontrast til guajás generelt ublide behandling af deres hunde. Kæleaberne får både personlige navne og slægtskabsbetegnelser, og kvinder, der har aborteret eller mistet deres spædbørn, får abeunger, som de kan amme. Der er således et ganske betragteligt antal aber i guajá-husholdene. Cormier peger på, at kæleabernes tilstedeværelse tjener som en markering af kvindelig fertilitet og udligner den asymmetri, der opfattes at herske mellem mænds og kvinders fertilitet. Mænd antages at have langt flere børn end kvinder, blandt andet fordi flere mænd kan fædre ét barn. Selv om Cormier betegner aberne som kæledyr, er der meget, der tyder på, at de i lige så høj grad kan betragtes som en særlig kategori af slægtninge.

9. Macfarlane peger dog på vidnesbyrd om, at kæledyrshold var et kendt fænomen blandt middelalderens velstillede familier før urbanisering og industrialisering (Macfarlane 1987:84-5).

10. Dette argument understøttes af Kathleen Kete i bogen The Beast in the Boudoir. Petkeeping in NineteenthCentury Paris (1994). For både det svenske og det parisiske borgerskab blev det at holde kæledyr kædet sammen med moderniteten. Det er også på det grundlag, dyrebeskyttelsesbevægelserne tog form. Kete påpeger, at det $\mathrm{i}$ Paris især var borgerskabets kvinder, der førte an i dyreværnsaktiviteterne. Forklaringen på dette kønnede engagement $\mathrm{i}$ dyrevelfærden var, foreslår Kete, at kvinderne i kraft af dette arbejde fandt en slags trøst og kompensation for den brutalitet, de mødte fra deres ægtefæller (Kete 1994:18). Löfgren peger endvidere på, at kæledyr også rummer et narcissistisk element, som er blevet forstærket det sidste århundrede. Dyr er gode kammerater, netop fordi ejeren kan forme dem efter sit eget ønske, skriver Löfgren (Löfgren 1985:199).

11. Carsten viser i sit studie af malay-samfundet, hvorledes forbundethed og slægtskab skabes og vedligeholdes over tid gennem hverdagspraksisser som at bo og spise sammen (Carsten 1997, 2000).

12. Gestatio betyder at bære, og gestationel forbundethed refererer til den forbundethed, der etableres i forbindelse med graviditet og fødsel.

13. Naboskab er et ikke uvæsentligt aspekt af dansk hverdagsliv, der rummer en væld af finurlige samværs- og udvekslingsformer.

\section{Litteratur}

Albert, Alexa \& Kris Bulcroft

1988 Pets, Families, and the Life Course. Journal of Marriage and the Family 50:543-52.

Bech-Jessen, Lars

1987 En lille. København: Gyldendal.

Belk, Russell W.

1996 Metaphoric Relationships with Pets. Society and Animals 4(2):121-45.

Bouquet, Mary

1993 Reclaiming English Kinship. Portuguese Refractions of British Kinship Theory. Manchester: Manchester University Press.

Carsten, Janet

1997 The Heat of the Hearth. The Process of Kinship in a Malay Fishing Community. Oxford: Clarendon Press. 
2000 Introduction: Cultures of Relatedness. I: Janet Carsten (ed.): Cultures of Relatedness. Cambridge: Cambridge University Press.

2004 After Kinship. Cambridge: Cambridge University Press.

Coates, Peter

1998 Nature. Western Attitudes since Ancient Times. Cambridge: Polity Press.

Cormier, Loretta A.

2003 Kinship With Monkeys. New York: Columbia University Press.

Danmarks Statistik

$2000 \quad$ Familiernes kæledyr. Nyt fra Danmarks Statistik nr. 499.

Franklin, Sarah

1997 Embodied Progress. ACultural Account of Assisted Conception. London \& New York:

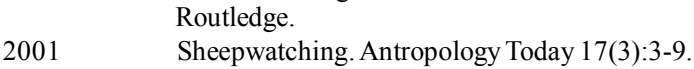

Fukuda, Kaoru

1997 Different Views of Animals and Cruelty to Animals. Cases in Fox-Hunting and Pet-Keeping in Britain. Anthropology Today 13(5):2-6.

Gillis, John

1996 A World of their Own Making. Myth, Ritual and the Quest for Family Values. New York: Basic Books.

Greenebaum, Jessica

2004 It's a Dog's Life: Elevating Status from Pet to "Fur Baby" at Yappy Hour. Society and Animals 12(2):117-35.

Hastrup, Kirsten

1999 Viljen til viden. En humanistisk grundbog. København: Gyldendal.

Holmberg, Lars

1996 Fjer om mulen ved morgengry: Om brugen af dyremetaforer i det danske politi. Tidsskriftet Antropologi 33:21-35.

Howell, Signe

2001

Self-Conscious Kinship. I: Sarah Franklin \& Susan McKinnon (eds.): Relative Values.

Reconfiguring Kinship Studies. Durham: Duke University Press.

Ingold, Tim

1994 Introduction. I: Tim Ingold (ed.): What is an Animal? London: Routledge.

Jarnved, Irene $\mathrm{H}$.

$2005 \quad$ Fra hvalp til hund. København: Aschehoug.

Kete, Kathleen

1994 The Beast in the Boudoir. Petkeeping in Nineteenth-Century Paris. Berkeley: University of California Press.

Leach, Edmund

1968 Anthropological Aspects of Language: Animal Categories and Verbal Abuse. I: Eric H.

Lenneberg (ed.): New Directions in the Study of Language. Cambridge: M.I.T. Press

Lévi-Strauss, Claude

1991 [1964] Totemism. London: Merlin Press.

Lundin, Susanne

1996 Longing for Social and Biological Identity. I: Jonas Frykman \& Orvar Löfgren (eds.): Force

of Habit. Exploring Everyday Culture. Lund: Lund University Press.

1999 The Boundless Body; Cultural Perspectives on Xenotransplantation. Ethnos 64(1):5-31. 
Löfgren, Orvar

1985 Our Friends in Nature. Class and Animal Symbolism. Ethnos 14(3-4):184-213.

Macfarlane, Alan

1987 The Culture of Capitalism. Oxford: Basil Blackwell Ltd.

Mosegaard, Maruska la Cour

2005 Faderskab og forbundethed. Et studie af homoseksuelle mænds forældreskab.

Kandidatspeciale. Institut for Antropologi, Københavns Universitet.

Nicolaisen, Ida

1996 Vi og vore hunde. Tidsskriftet Antropologi 33:99-116.

Papagaroufali, Eleni

1996 Xenotransplantation and transgenesis. Im-Moral Stories about Human-Animal Relations in the West. I: Philippe Descola \& Gisli Pálsson (eds.): Nature and Society. London: Routledge.

Reddy, G. Prakash

1998 Danske dilemmaer. Mørke: Grevas Forlag.

Sanders, Clinton R.

1993 Understanding Dogs. Caretakes'Attributions of Mindedness in Canine-Human Relationships. Journal of Contemporary Ethnography 22(2):205-26.

1999 Understanding Dogs. Living and Working with Canine Relationships. Philadelphia: Temple University Press.

Savishinsky, Joel

1985 Pets and Family Relationships Among Nursing Homes Residents. I: Marvin B. Sussman (ed.): Pets and the Family. New York: The Haworth Press.

Schiebinger, Londa

1993 Nature's Body. Gender in the Making of Modern Science. Boston: Beacon Press.

Schneider, David M.

$1968 \quad$ Virgin Birth. Man 3(1):126-8.

1980 American Kinship. A Cultural Account. Chicago: University of Chicago Press.

1984 The Critique of Kinship. Ann Arbor: University of Michigan Press.

Strathern, Marilyn

1992a After Nature: English Kinship in the Late Twentieth Century. Cambridge: Cambridge University Press.

1992b Reproducing Future. Anthropology, Kinship and the New Reproductive Technologies. Manchester: Manchester University Press.

Tapper, Richard L.

1994 Animality, Humanity, Morality, Society. I: Tim Ingold (ed.): What is an Animal? London: Routledge.

Tjørnhøj-Thomsen, Tine

1999 Tilblivelseshistorier. Barnløshed, slægtskab og forplantningsteknologi i Danmark. Ph.d.-

rækken nr. 12. Institut for Antropologi, Københavns Universitet.

2003a Childlessness, Procreative Technologies and Creation of New Mythologies. Folk 45:33-59.

2003b Samværet. Tilblivelser i tid og rum. I: Kirsten Hastrup (red.): Ind i verden. En grundbog i antropologisk metode. København: Hans Reitzels Forlag.

2004 Slægtskab. Tilblivelse, forbundethed og fællesskab. I: Kirsten Hastrup (red.): Viden om verden. En grundbog i antropologisk analyse. København: Hans Reitzels Forlag.

Tsing, Anna Lowenhaupt

1995 Empowering Nature, or: Some Gleanings in Bee Culture. I: Sylvia Yanagisako \& Carol Delaney (eds.): Naturalizing Power. Essays in Feminist Cultural Analysis. London: Routledge. 
Turner, Victor

The Forest of Symbols. Ithaca: Cornell University Press.

Yanagisako, Sylvia \& Carol Delaney

1995 Naturalizing Power. I: Sylvia Yanagisako \& Carol Delaney (eds.): Naturalizing Power.

Essays in Feminist Cultural Analysis. London: Routledge. 